\title{
Cranial morphometry and taxonomy of argali, Ovis ammon (Artiodactyla, Bovidae), from former Soviet Union and Mongolia
}

\author{
Darya V. Kapitanova, Alexey V. Lopatin, Andrey E. Subbotin \& William A. Wall
}

\begin{abstract}
A partial revision of the subspecies taxonomy of argali Ovis ammon was done on the basis of cranial features using the modern statistical methods (discriminant analysis, cluster analysis, multidimensional scaling). Skulls of mature males from different populations of the former Soviet Union and Mongolia were studied. A system of measurements and characters was developed for the thorough description of the skull and its bones. Three discrete cranial types were distinguished: Nuratau (O. a. severtzovi), KyrgyzKazakhstan (O. a. nigrimontana, O. a. polii, and O. a. karelini) and Mongolian (O. a. ammon and $O$. $a$. darwini). A clear isolation of $O$. a. severtzovi from other argalis was noted, as well as from moufflons and urials. Differences between $O$. a. collium and O. a. karelini do not attain the subspecies level; therefore, these forms are combined into the subspecies $O$. a. karelini. O. a. ammon and O. a. darwini form a group isolated from other argalis and differentiated into two subspecies based on the discriminant analysis.
\end{abstract}

KEY WORDS: Ovis ammon, cranial morphometry, subspecies level taxonomy, Kyrgyzstan, Kazakhstan, Tajikistan, Uzbekistan, Mongolia.

Darya V. Kapitanova [kpd81@mail.ru], Severtzov's Institute of Ecology and Evolution, Russian Academy of Sciences, Leninsky pr. 33, Moscow 119071, Russia; AlexeyV. Lopatin [alopat@paleo.ru], Paleontological Institute, Russian Academy of Sciences, ul. Profsoyuznaya 123, Moscow 117647, Russia; Andrey E. Subbotin [asubbotin@sevin.ru], Severtzov's Institute of Ecology and Evolution, Russian Academy of Sciences, Leninsky pr. 33, Moscow119071,Russia; William A.Wall [bwall@sci-dc.org; wawall900@earthlink.net], Safari Club International Foundation, $5012^{\text {nd }}$ Street, NE, Washington, D.C. 20002, USA.

\section{Краниальная морфометрия и таксономия архаров Ovis ammon (Artiodactyla, Bovidae) территории бывшего СССР и Монголии}

\author{
Д.В. Капитанова, А.В. Лопатин, А.Е. Субботин, У.А. Уолл
}

\begin{abstract}
РЕЗЮМЕ. Проведена частичная ревизия подвидовой систематики архара Ovis ammon на основе краниологических признаков с использованием современных методов статистики (дискриминантный анализ, кластерный анализ, многомерное шкалирование). Исследованы черепа половозрелых самцов из разных популяций с территории бывшего СССР и Монголии. Разработана система промеров и индексов, детально описывающих строение черепа и составляющих его костей. Выделены три дискретных краниальных типа: нуратинский (O. a. severtzovi), киргизско-казахстанский (O.a. nigrimontana, O. a. polii и O. a. karelini) и монгольский (O. a. ammon и O. a. darwini). Отмечена четкая обособленность барана Северцова как от других представителей группы архаров, так и от муфлонов и уриалов. Различия между O. a. collium и O. a. karelini не достигают подвидового уровня, поэтому эти формы объединены в один подвид O. a. karelini. O. a. ammon и O. a. darwini образуют хорошо обособленную от других архаров группу, по результатам дискриминантного анализа дифференцированную на два подвида.
\end{abstract}

КЛЮЧЕВЫЕ СЛОВА: Ovis ammon, краниальная морфометрия, подвидовая систематика, Киргизстан, Казахстан, Таджикистан, Узбекистан, Монголия.

\section{Introduction}

The taxonomy of wild sheep (genus Ovis L.) has been developed since the late $19^{\text {th }}$ century. The works of Severtzov (1873), Lydekker (1898), Nasonov (1923), and Tsalkin (1951) are of fundamental value. The systems of these scientists were mainly based on the differences in cranial proportions, the direction of horn twisting, and some other external morphological features such as wool color, presence of a ruff, and total body size. The geographical confinement of habitats was the main criterion for the separation into species and subspecies. The results of these studies are contradictory and reflect the development from the typological to polytypic concept of mammal species (Vorontsov et al., 1972). No clear idea has been proposed up to now. The position of one of the above researchers is usually followed in the present-day works on the mammal taxonomy.

The study of chromosome sets in the geographical forms of sheep revealed four genome types in the group: 
52-chromosome snow sheep (O. nivicola), 54-chromosome moufflons $(O$. musimon and $O$. orientalis $)$ and North-American bighorn sheep $(O$. canadensis and $O$. dalli), 56-chromosome argalis and $\operatorname{arkhars}(O$. ammon), and 58-chromosome urials (O. vignei) (Vorontsov et al., 1972; Korobitsyna et al., 1974). However, some species differing in chromosome sets can be ranked among subspecies, because data are available that the reproductive isolation of 54-, 56-, and 58-chromosome wild sheep is evidently imperfect, if any (Orlov, 1978). In this approach, the genus $O v i s$ includes two species $(O$. ammon and $O$. canadensis), which in turn include subspecies with different numbers of chromosomes (Orlov, 1978).

These disagreements called for the revision of the subspecies taxonomy of the group and the establishment of taxonomic ranks of geographical forms better defined in morphological terms. Sopin (1982) analyzed 13 parameters describing the cranial proportions and some bones for a series of adult argali males. Along with craniological features, color variation was also considered. Sopin confirmed the subspecies rank of $O$. $a$. nigrimontana, O. a. ammon, O. a. darwini, O. a. kozlovi, O. a. dalailamae, and O. a. hodgsoni and combined three forms O. a. karelini (Tien Shan), O. a. polii (Pamirs) and O. a. collium (Kazakhstan hillocky area) into the subspecies $O$. a. polii. The Mayr coefficients of discrimination (calculated as the ratio of the difference between the mean values of a parameter in the samples compared to the sum of standard deviations) were used as an analytical tool. However, Mayr (1969) noted that coefficients of discrimination give only approximate estimates, because their calculation is based on inexact assumptions (e.g., that the distributions are normal and that statistic characteristics of a sample are equal to those of the whole population). This calls into question the results obtained. Most authors are inclined to consider $O$. a. polii as an argali subspecies well distinguished from O. a. collium and O. a. karelini, in spite of the hybridization zone existing between $O$. a. polii and O. a. karelini at the boundary of their ranges (Nasonov, 1923; Rumyantsev, 1935; Tsalkin, 1951). As for the karelini and collium forms, many authors consider them very close to each other (Tsalkin, 1951; Heptner et al., 1961; Sludskii et al., 1983): the only differences in the premaxilla length, which is longer in the collium form (Tsalkin, 1951), and in the character of horn twisting (Nasonov, 1923) were noted.

Of great interest is the taxonomic position of Severtzov's argali inhabiting the Nuratau and Aktau ranges, the southeastern Kyzyl-Kum Desert. Almost all authors note the intermediate morphological position of this form between argalis and urials. Nasonov (1923) described this form as an $O$. polii subspecies, although he noted its traits in common with sheep of the group "Mufloniformes". In later investigations, the severtzovi form was ranked among urials as $O$. vignei severtzovi (Gromov \& Baranova, 1981), among moufflons as $O$. orientalis severtzovi (Red Book of the Kazakh SSR, 1978), or, in the case of the extensive interpretation of the species O. ammon, among moufflons (Tsalkin, 1951; Sokolov, 1959; Heptner et al., 1961; Vorontsov et al., 1972). After a thorough study of its horns, Ishunin (1968) supposed that the Severtzov's argali is closer to the Karatau sheep than to the western strains. Valdez (1982) ranked the Severtzov's argali among urials. Sopin (1982) did not consider the severtzovi form in the analysis of argali subspecies, apparently placing it among urials. More recently, Sopin (1984) concluded that the Severtzov's argali is much closer to Karatau sheep (nigrimontana form) than to urials and ranked it among argalis as a subspecies. The study of the Severtzov's wild sheep karyotype undoubtedly showed that it belongs to the so called arkhar-argaloid group of sheep, Ovis ammon s. str., although, in macromorphological terms, the Severtzov's sheep occupies an intermediate place between urials and argalis (Lyapunovaet al., 1997).

When studying the geographical diversity of argalis in the Mongolian and Russian Altai regions, Sopin \& Sukhbat (1980) noted significant differences in the skull size and its variation between these two populations. Nonetheless, they concluded that the populations are morphologically close and that the noted differences are of population rank. Later on, these authors studied the populations of Mongolian and Gobi Altai for determining their taxonomic ranks (Sopin \& Sukhbat, 1983). They revealed reliable differences in skull sizes (Mongolian Altai argalis are bigger than the sheep of Gobi Altai) and cranial proportions (Gobi Altai argalis have shorter and narrower skulls). Therefore, a conclusion about the subspecies status of both populations was drawn.

Valdez (1982) postulated the existence of six argali subspecies: $O$. a. ammon $(=O$ a a. mongolica, $O$. $a$. jubata), O. a. nigrimontana, O. a. darwini, O. a. hodgsoni (=O. a. blythi, O. a. brookei, O. a. dalailamae, O. a. adametzi), O. a. polii, and O. a. karelini $(=O$. a. heinsii, O. a. collium, O. a. sairensis, O. a. littledalei, O. a. humei).

Geist (1991) analyzed differences between the geographical forms of argalis from the nuptial coat of males (wool color during the rutting season). In a thorough review of works on the taxonomy of this group, Geist made criticisms on the procedure used; e.g., he indicates the absence of statistical analysis of the results, incomplete description of the geographical forms, and inexact gridding of specimens. Geist divides the species into seven subspecies: $O$. a. nigrimontana, O. a. hodgsoni, O. a. jubata, O. a. darwini, O. a. ammon, O. a. polii and O. a. karelini.

It is noteworthy that Valdez and Geist combine the collium and karelini forms.

Fedosenko (2000) states the existence of eight subspecies: O. a. polii (Pamir or Marco Polo argali), O. a. collium (Karaganda or Kazakhstan argali), O. a. kareli$n i$ (Tien Shan argali), O. a. nigrimontana (Karatau argali), O. a. severtzovi (Severtzov's argali), O. a. ammon (Altai argali), O. a. darwini (Gobi or Darwin argali), O. a. hodgsoni (Tibetan argali) and O. a. jubata (North China argali). 


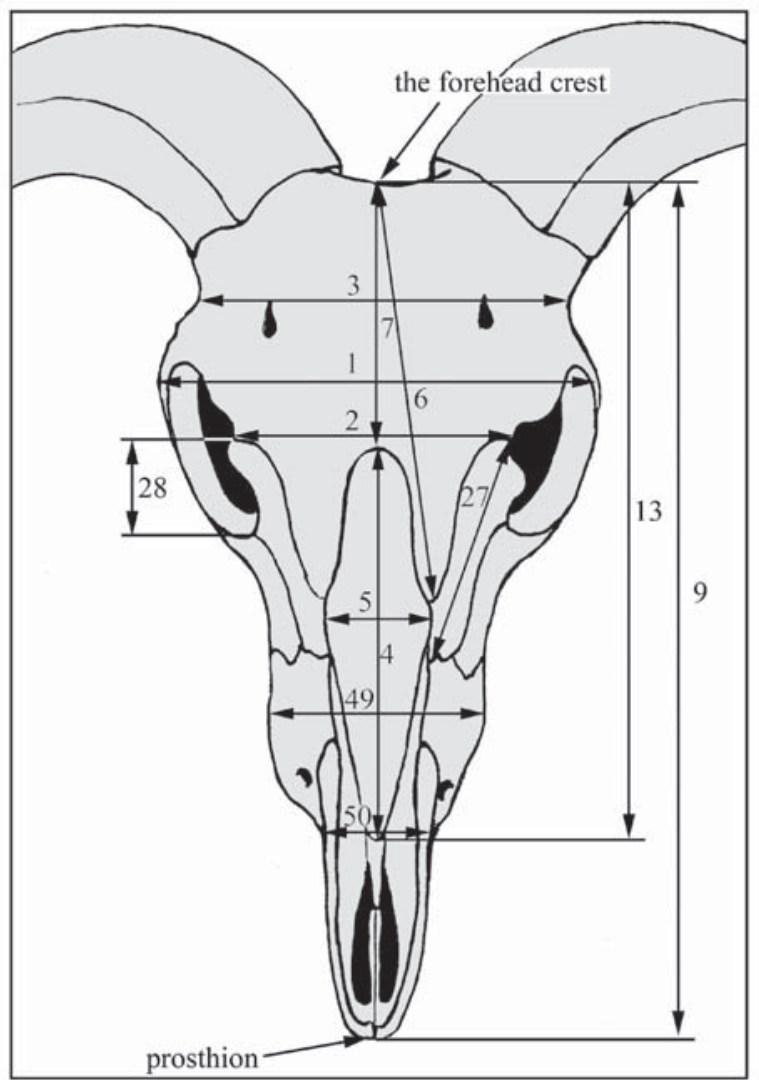

Figure 1. Cranial measurements of Ovis ammon, dorsal view, see Appendix 1 for the explanation of measurements.
Current molecular-genetic methods still cannot solve the main problems of argali taxonomy. The comparison of specific sequences in the mitochondrial DNA of the nigrimontana, severtzovi, hodgsoni, dalailamae, adametzi, sairensis and darwini forms showed that the nigrimontana form diverges first, followed by the severtzovi form (Wu et al., 2003). The other forms constitute three clades, one of which includes only darwini individuals; the second clade includes adametzi and sairensis samples, and the third clade is composed of hodgso$n i$ and dalailamae animals. Thus, the nigrimontana and severtzovi forms are considered argali subspecies, and hodgsoni and dalailamae are combined into the same genetic group.

The comparison of the mtDNA sequences of Mongolian sheep showed that the subspecies $O$. a. ammon alone inhabits the territory studied (Altai, Hangai, and Gobi). The analysis revealed the higher genetic variability within the populations than among them. The authors attribute the results obtained to the existence of gene flux between the populations, mainly due to the migration of females, as well as to the relatively recent divergence of populations (Tserenbataa et al., 2004).

In this paper, the subspecies taxonomy of Ovis ammon inhabiting the territories of Tajikistan, Uzbekistan, Kyrgyzstan, Kazakhstan, and Mongolia is revised on the basis of morphometric and morphological analyses of cranial features using the modern statistical methods and significant body of data. The following tasks were set: (1) to identify the significant craniological features, both quantitative and qualitative ones, and to develop

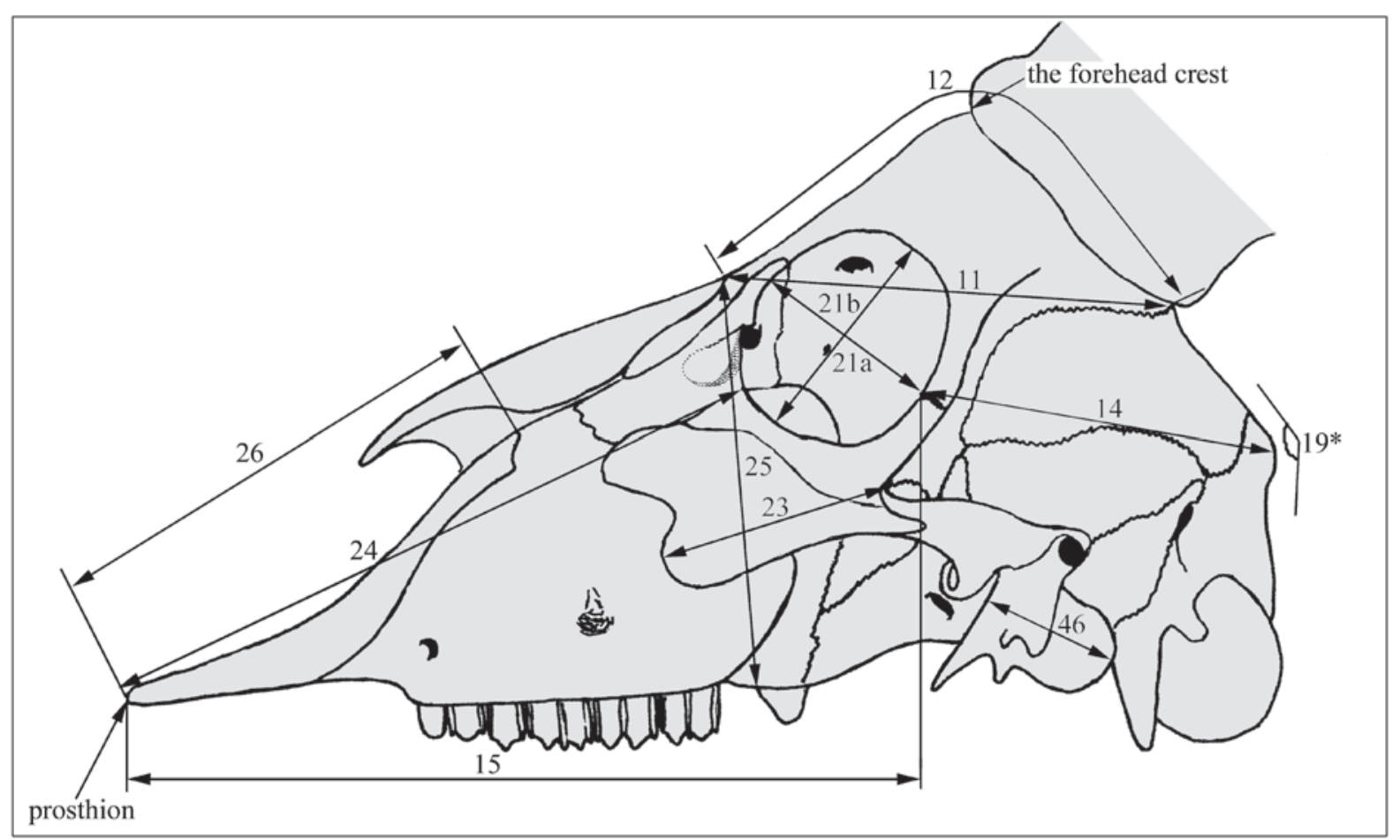

Figure 2. Cranial measurements of Ovis ammon, lateral view, see Appendix 1 for the explanation of measurements. 


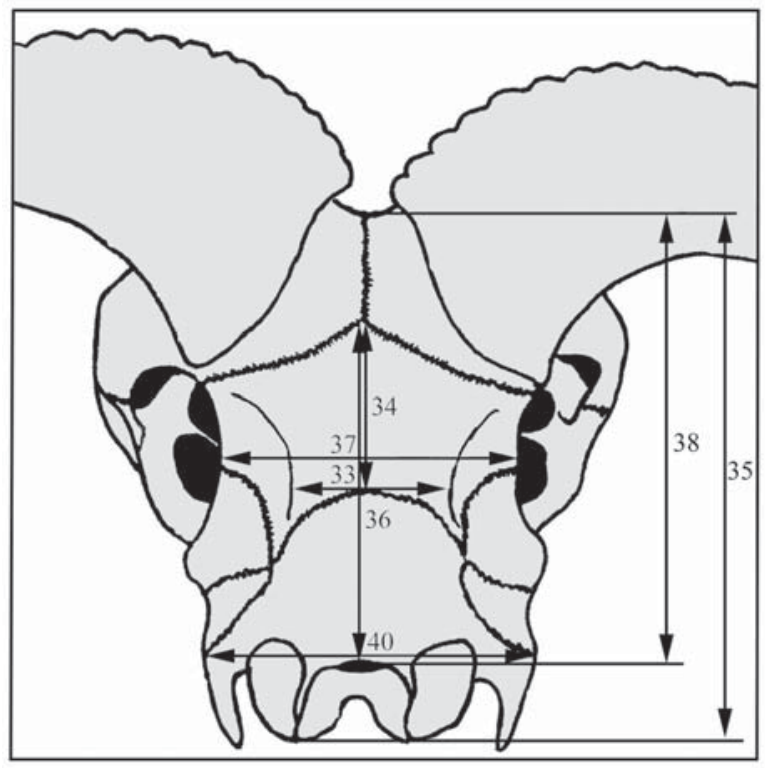

Figure 3. Cranial measurements of Ovis ammon, posterior view, see Appendix 1 for the explanation of measurements.

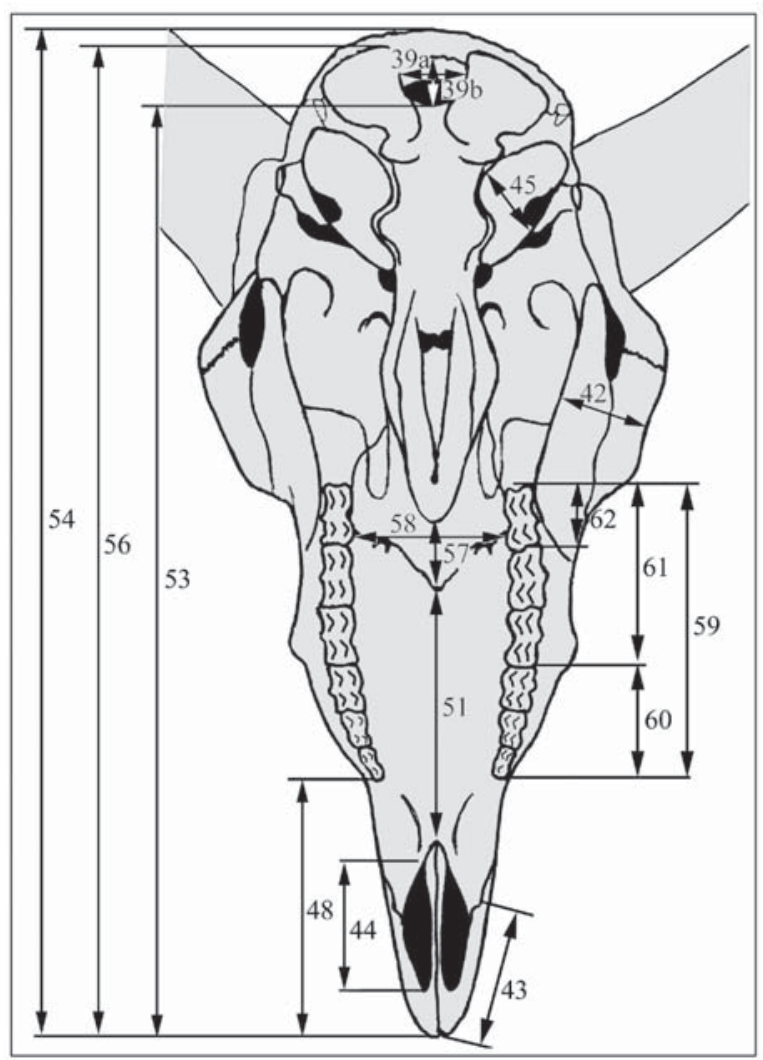

Figure 4. Cranial measurements of Ovis ammon, ventral view, see Appendix 1 for the explanation of measurements.

procedures for morphometric analysis; (2) to perform the statistical analysis of data; (3) to determine the evolutionary-morphological trend and to propose a hypothesis about the phylogenetic relations among subspecies; and (4) to propose a hypotheses about the

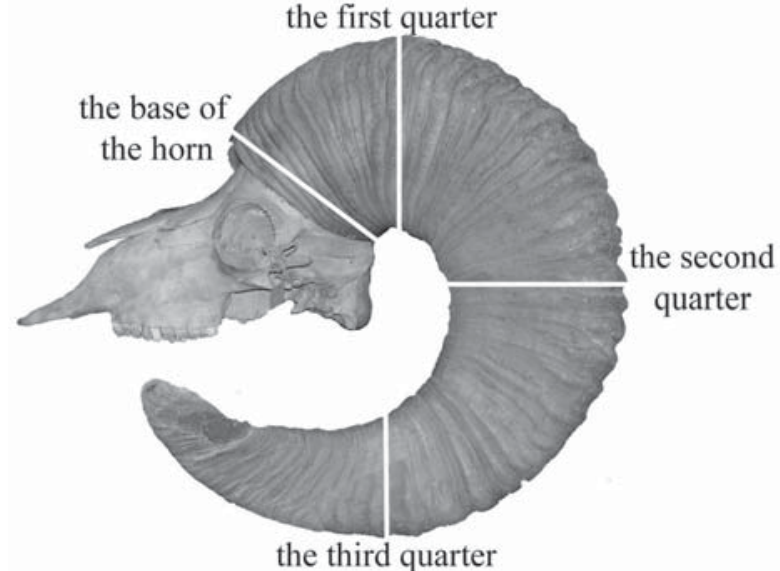

Figure 5. Horn measurements of Ovis ammon, lateral view, see Appendix 1 for the explanation of measurements.

taxonomic ranks of the populations studied and to revise the subspecies taxonomy of Ovis ammon on the basis of the analysis performed.

\section{Methods}

The work was conducted on skull samples from collections of the Zoological Museum, Moscow State University, Moscow (MSU ZM); the Zoological Institute of the Russian Academy of Sciences, St. Petersburg (ZIN); and the Institute of the Zoology and Animal Gene Fund of the Ministry of Education and Science of Kazakhstan Republic, Almaty (IZAG KR).

A total of 219 skulls of mature males of 4 years and older were included in the study. Both whole skulls and insignificantly damaged ones (without premaxilla, nasal, horn shells) were used. The age was determined by the calculation of horny rings; in the absence of horn shells, the approximate determination was based on the tooth wear stage for adult specimens and the stage of replacement of deciduous teeth by permanent ones for young specimens.

Measurements were conducted with beam compass, toolbar, tape-measure, and bow compass. The accuracy of beam compass measurements was $0.1 \mathrm{~mm}$.

Measurements and qualitative characters are listed in Appendix 1; measurement patterns are shown in Figs. $1-6$. The index ratios included in the statistical analysis are given in Appendix 2.

The analysis also included some absolute index values describing the cranial proportions on the whole (Appendix 1: characters 1, 9, 35, 54, 68, 82).

The range under study included Mongolian and Gobi Altai, Sailyugem Range, Transaltai and Junggar Gobi, Tarbagatai and Manyrak ranges, regions of Zaisan and Ebinur lakes, Kazakhstan hillocky area, eastern Betpak-Dala, Kastek Ridge (Zailiiskii Alatau), Terskei Alatau, Talass Alatau, Aleksandr Range, Karatau, Ak- 


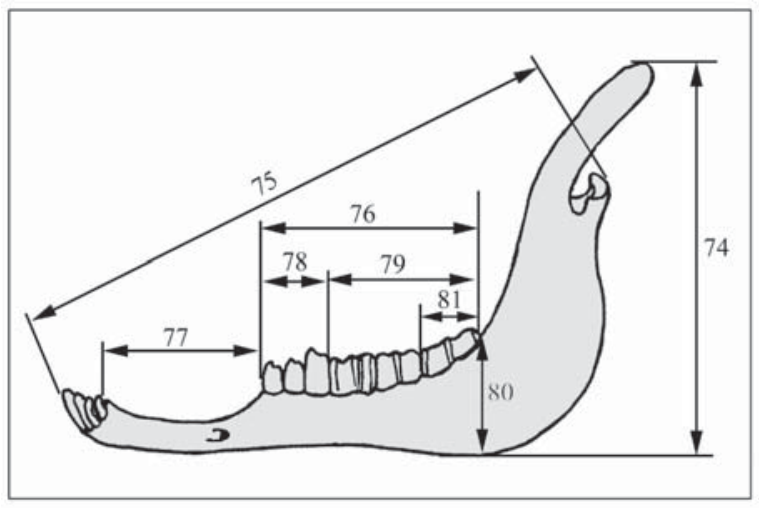

Figure 6. Mandible measurements of Ovis ammon, lateral view, see Appendix 1 for the explanation of measurements.

tau, Nuratau ranges and the Pamirs (Tab. 1). Three Asiatic moufflons (O. orientalis, O. gmelini, and $O$. ophion) and two urials (O. vignei) from the western range of the genus (Turkey, Isphahan, Usturt, Laristan, and Eastern Bukhara) constituted the outer group (Fig. 7).

Some of argali habitats within the range studied were combined (and conventionally named as 'regions') to increase the size of samples and to verify the hypothesis about the existence of independent subspecies on these territories (Tab. 1).

The analysis of qualitative characters was based on the sample of adult males 4.5 to 8 years of age from Mongolian Altai, Gobi Altai, Kazakhstan hillocky area,
Table 1. Geographic distribution of the studied Ovis ammon specimens.

\begin{tabular}{|c|c|c|c|}
\hline Region & $\begin{array}{c}\text { Subspecies } \\
\text { name }\end{array}$ & Habitats/populations & $\begin{array}{l}\text { Number of } \\
\text { specimens }\end{array}$ \\
\hline \multirow{2}{*}{ Altai } & \multirow{2}{*}{ O. a. ammon } & Mongolian Altai & \multirow{2}{*}{24} \\
\hline & & Sailyugem Range & \\
\hline \multirow{3}{*}{ Gobi } & \multirow{3}{*}{ O. a. darwini } & Gobi Altai & \multirow{3}{*}{28} \\
\hline & & Transaltai Gobi & \\
\hline & & Junggar Gobi & \\
\hline \multirow{4}{*}{$\begin{array}{l}\text { Semire- } \\
\text { chensk } \\
\text { region }\end{array}$} & \multirow{4}{*}{ O. a. karelini } & Zailiiskii Alatau & \multirow{4}{*}{42} \\
\hline & & Talass Alatau & \\
\hline & & Aleksandr Range & \\
\hline & & Terskei Alatau & \\
\hline \multirow{4}{*}{$\begin{array}{l}\text { Hillocky } \\
\text { area }\end{array}$} & \multirow{4}{*}{ O. a. collium } & Tarbagatai & \multirow{4}{*}{55} \\
\hline & & Zaisan and Ebinur lakes & \\
\hline & & Eastern Betpak-Dala & \\
\hline & & Kazakhstan hillocky area & \\
\hline Pamirs & O. a. polii & Pamirs & 43 \\
\hline Karatau & $\begin{array}{c}O . a . \\
\text { nigrimontana }\end{array}$ & Karatau Range & 16 \\
\hline \multirow{2}{*}{ Nuratau } & \multirow{2}{*}{$\begin{array}{c}O . a . \\
\text { severtzovi }\end{array}$} & Nuratau Range & \multirow{2}{*}{6} \\
\hline & & Aktau Range & \\
\hline
\end{tabular}

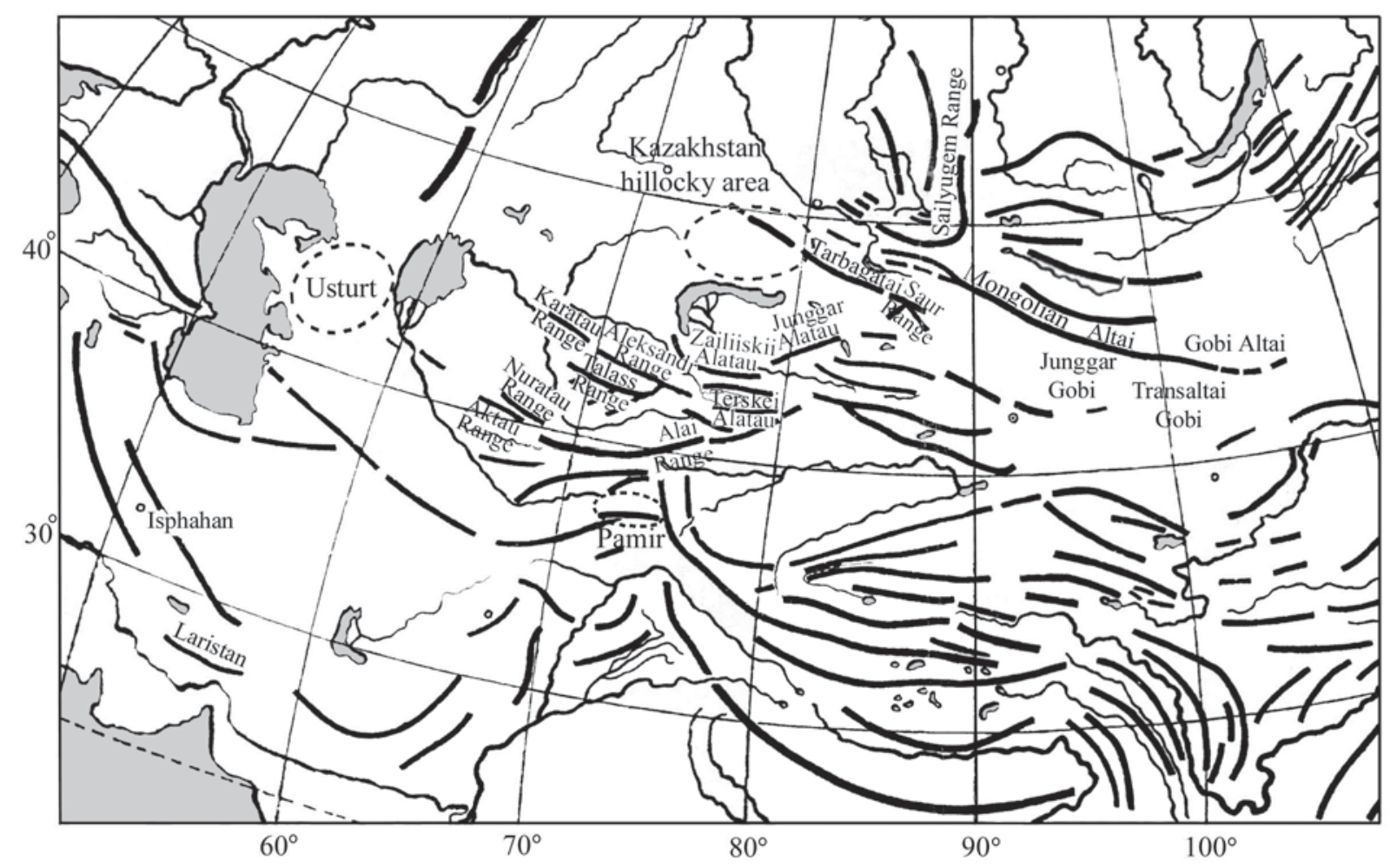

Figure 7. Orographic scheme of the distribution of the Ovis ammon subspecies studied. 
Table 2. Significant cranial characters included into the stepwise discriminant model.

\begin{tabular}{|c|c|c|}
\hline Character & F-remove & p-level \\
\hline Total horn span/distance between horn tips & 21.666 & 0.000 \\
\hline Distance between parietal crests / parietal length & 3.770 & 0.000 \\
\hline Total breadth & 13.402 & 0.000 \\
\hline Total breadth / forehead crest - frontal-nasal suture distance & 7.145 & 0.000 \\
\hline Basal hom circumference / horn circumference at the second quarter & 4.828 & 0.000 \\
\hline Skull height & 11.755 & 0.000 \\
\hline Skull height / total breadth & 6.749 & 0.000 \\
\hline Nasal length / nasal breadth & 2.746 & 0.005 \\
\hline Foramen magnum diameter ratio & 4.075 & 0.000 \\
\hline Horn length / total horn span & 7.340 & 0.000 \\
\hline Horn length & 8.644 & 0.000 \\
\hline Forehead crest - frontal process distance / forehead crest - frontal-nasal suture distance & 5.297 & 0.000 \\
\hline Forehead crest - prosthion distance / forehead crest - anterior nasal edge distance & 3.564 & 0.000 \\
\hline Condylobasal length / skull height & 3.095 & 0.002 \\
\hline $\begin{array}{l}\text { Forehead crest-foramen magnum distance / parietal-frontal suture - } \\
\text { foramen magnum distance }\end{array}$ & 2.813 & 0.004 \\
\hline Total length & 6.409 & 0.000 \\
\hline Forehead crest - prosthion distance / total breadth & 5.149 & 0.000 \\
\hline Forehead crest - prosthion distance / condylobasal length & 3.493 & 0.000 \\
\hline Lower cheek tooth row length / lower molar tooth row length & 3.114 & 0.002 \\
\hline Lacrimal bone length / lacrimal bone breadth & 3.483 & 0.000 \\
\hline Total breadth / interorbital breadth & 3.243 & 0.001 \\
\hline Basal horn circumference / horn circumference at the third quarter & 3.080 & 0.002 \\
\hline Upper premolar row length / upper molar row length & 3.059 & 0.002 \\
\hline Occipital breadth / greater foramen magnum diameter & 2.893 & 0.003 \\
\hline Tympanic bulla length / tympanic bulla breadth & 2.921 & 0.003 \\
\hline Upper cheek tooth row length / distance between cheek tooth rows & 2.765 & 0.004 \\
\hline Mandible length / total mandible depth & 2.580 & 0.008 \\
\hline
\end{tabular}

Semirechye, Karatau, and the Pamirs. To find out whether the groups are distinguishable by qualitative characters, the frequencies of occurrence were calculated for all character variations in each region. The frequency of occurrence of a form was calculated as the ratio between the number of animals with the occurrence of a specific character and the total number of animals in the group. The values obtained for regions were compared.

The statistical processing of the data collected was performed using the Statistica 6.0 software.

To exclude the effect of size on the classification results, the basic data were preliminary standardized.

The classification of animals was performed using the stepwise discriminant analysis. The table column with the subspecies names was taken as the grouping variable. Empty cells were automatically filled with the character value averaged for the column. The forward stepwise procedure was used to reveal the most signifi- cant classification characters $(\mathrm{p} \leq 0.01, \mathrm{~F}$ to enter $=3.0, \mathrm{~F}$ to remove $=2.5$ ). The characters used were not grouped in relation to cranium, horny shells, and mandible.

The cluster analysis, which estimates the distances between groups, was based on the standardized average values of all characters for each region. Euclidian distances between groups were used; clusters were combined using the single linkage method. From the table of standardized average values, a hierarchical tree was constructed.

When analyzed by the multidimensional scaling method we used the matrices of distances between different groups. The matrices included the squared Mahalanobis distances calculated by the stepwise discriminant analysis. From the matrices obtained, the distribution graphs of geographical groups were plotted in the two-dimensional space of multidimensional scaling axes. 


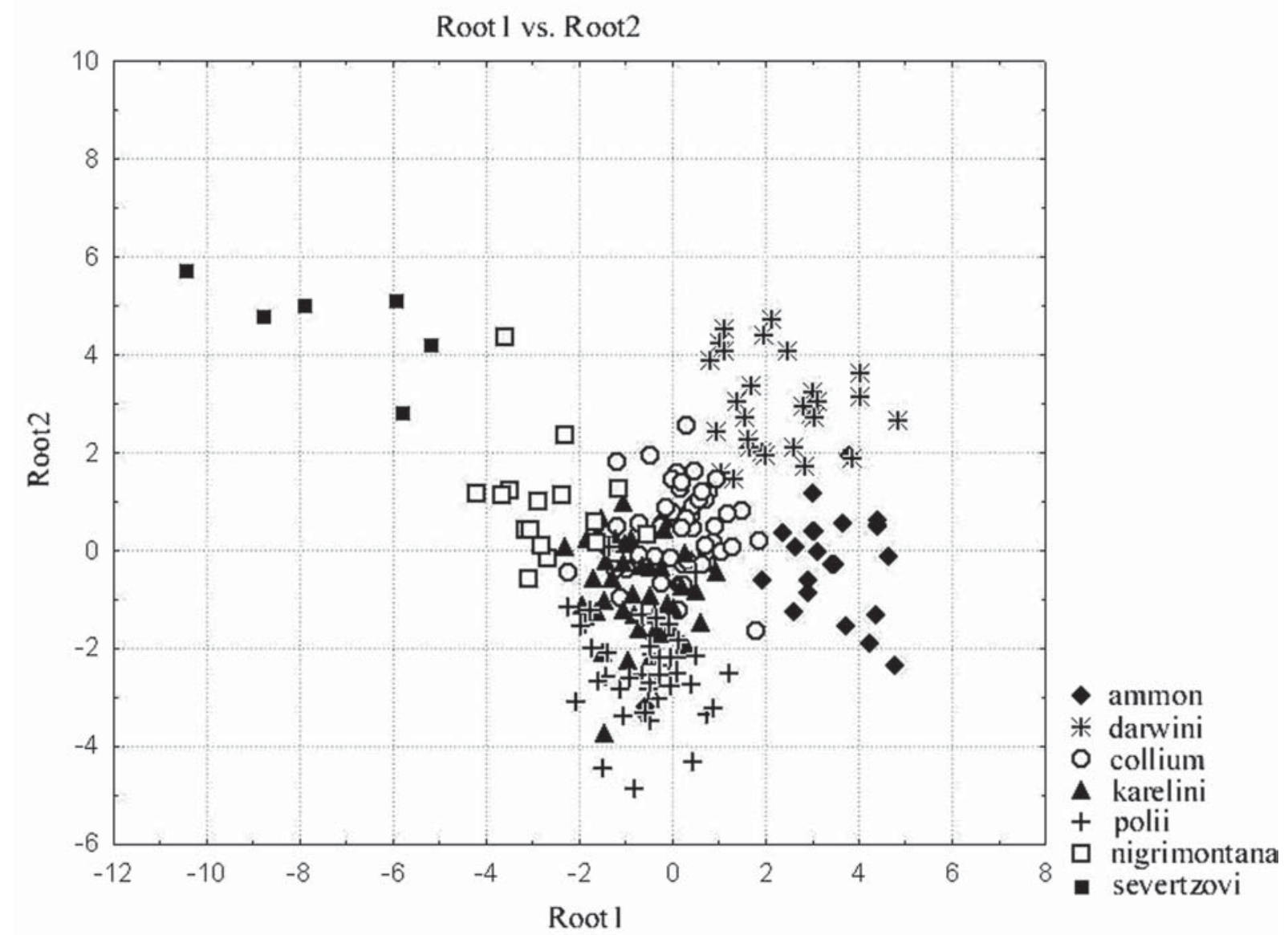

Figure 8. Scatterplot of Mahalanobis distances from discriminant analysis of skull measurements of Ovis ammon groups.

\section{Results}

\section{Discriminant analysis}

The sample included a total of eight geographical groups denoted in plots and tables as follows: ammon (Mongolian Altai), darwini (Gobi Altai), collium (Kazakhstan hillocky area), karelini (Semirechensk region), polii (Pamirs), nigrimontana (Karatau Range), severtzovi (Nuratau Range), and so called 'West' (the outer group of Asiatic moufflons and urials).

The comparison of all geographical groups between themselves (except of the outer group) by the stepwise discriminant analysis distinguished three cranial types in the group of Ovis ammon subspecies. The significant characters included in the model are given in Tab. 2.

The first type characterizes the Nuratau sheep; it is seen that this group is remote from the others (Fig. 8). The scattering diagrams of the other groups are strongly overlapping, which suggests that the groups are significantly closer to one another than to the severtzovi group.

The severtzovi group being excluded, the other groups are divided into two types; one of them includes Mongolian populations (ammon and darwini), and the other includes the polii, karelini, collium, and nigri- montana groups (Fig. 9). The samples of ammon and darwini overlap only slightly. In the latter type, polii and nigrimontana are located in the periphery, and polii is overlapping with karelini relatively slightly. For ease of discussion, the former type is below named Mongolian and the latter is named Kyrgyz-Kazakhstan.

The matrix of squared Mahalanobis distances for all groups clearly demonstrates the relations among the groups (Tab. 3). The outer (West) group is at a significant distance from the Ovis ammon groups. The severtzovi group is the closest to it, and the Mongolian Altai (ammon) group is the most remote from it.

The severtzovi group is intermediate between the other Ovis ammon groups and the outer group. It is remote from the West group; the distance between it and other groups is shorter. The nigrimontana group is the closest to and the ammon group is the most remote from the severtzovi group.

The relations among the groups within the distinguished cranial types are also presented in Tab. 3 . The ammon and darwini groups are relatively close to each other and similarly related to other groups: the collium group is the closest to them, and the nigrimontana group is relatively distant. On the whole, the darwini group is closer to the Kyrgyz-Kazakhstan groups than the am- 


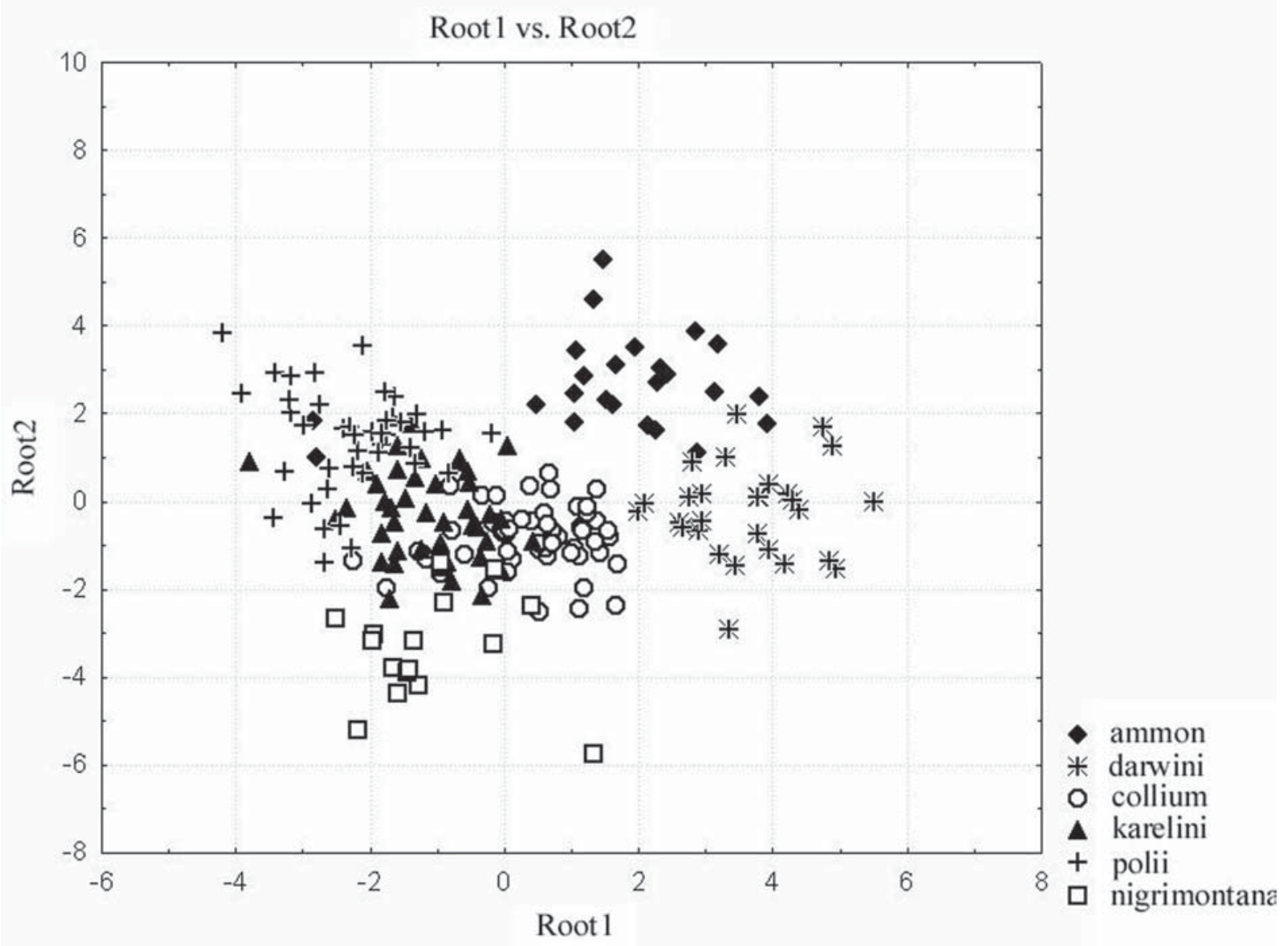

Figure 9. Scatterplot of Mahalanobis distances from discriminant analysis of skull measurements of Ovis ammon groups apart from $O$. a. severtzovi.

mon group. An exception is provided by the polii group, which is significantly closer to the ammon than to darwini group.

The collium and karelini groups are very close to each other. A strong overlapping of their scattering diagrams is seen in Fig. 9; the distance between them is the shortest in the matrix (Tab. 3). The other two Kyrgyz-Kazakhstan groups are very similar with respect to these samples. The polii and nigrimontana groups are closer to the karelini than to collium group. The polii and nigrimontana groups are relatively distant from each other; their scattering clouds are not overlapping.

\section{Cluster analysis and multidimensional scaling}

Cluster analysis clearly demonstrates interrelations and distances between the samples. They form two isolated groups, one of which consists of the outer (West) group, and the other includes all the samples

Table 3. Matrix of squared Mahalanobis distances.

\begin{tabular}{|l|c|c|c|c|c|c|c|c|}
\hline & ammon & darwini & collium & karelini & polii & West & nigrimontana & severtzovi \\
\hline ammon & 0.000 & 12.104 & 15.274 & 18.593 & 21.064 & 377.259 & 43.486 & 135.251 \\
\hline darwini & 12.104 & 0.000 & 16.349 & 23.341 & 32.741 & 329.967 & 33.605 & 112.299 \\
\hline collium & 15.274 & 16.349 & 0.000 & 6.986 & 15.297 & 328.196 & 16.151 & 96.894 \\
\hline karelini & 18.593 & 23.341 & 6.986 & 0.000 & 8.268 & 325.028 & 10.205 & 88.957 \\
\hline polii & 21.064 & 32.741 & 15.297 & 8.268 & 0.000 & 349.947 & 20.943 & 98.335 \\
\hline West & 377.259 & 329.967 & 328.196 & 325.028 & 349.947 & 0.000 & 283.007 & 246.107 \\
\hline nigrimontana & 43.486 & 33.605 & 16.151 & 10.205 & 20.943 & 283.007 & 0.000 & 68.075 \\
\hline severtzovi & 135.251 & 112.299 & 96.894 & 88.957 & 98.335 & 246.107 & 68.075 & 0.000 \\
\hline
\end{tabular}




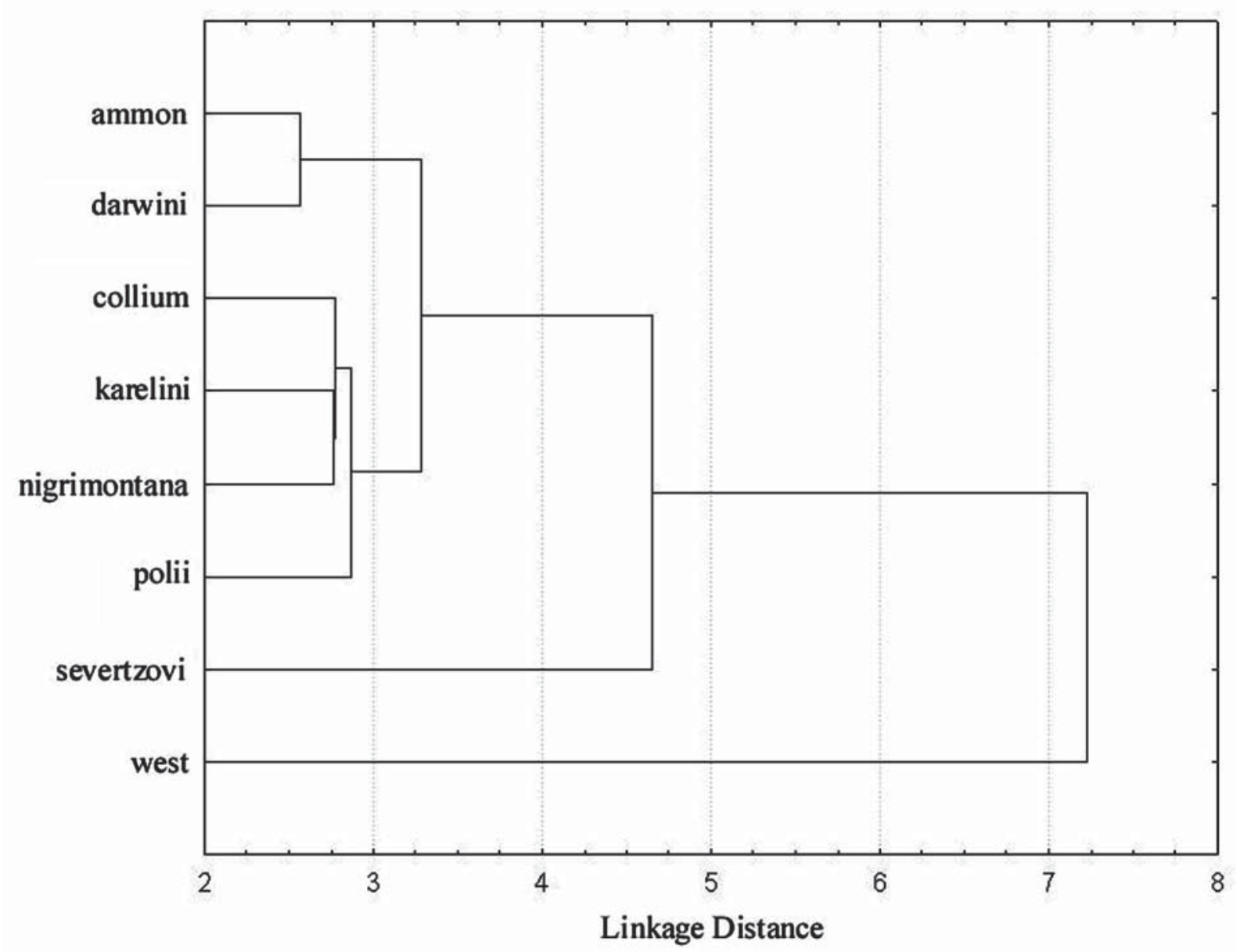

Figure 10. Hierarchical tree of the studied Ovis ammon groups based on cluster analysis.

studied (Fig. 10). The second group is split into three clusters corresponding to three cranial types. The first cluster consists of the severtzovi group, which is sufficiently remote from the other argali groups. The second cluster includes the Kyrgyz-Kazakhstan samples, with equal and short distances between them within the cluster. The third cluster is composed of the Mongolian ammon and darwini groups; the distances between them are the shortest in the plot.

The multidimensional scaling method presents the distribution of the groups in the two-dimensional space. The graph was plotted using squared Mahalanobis distances between the groups. The distances between the severtzovi and outer groups, on one side, and the other groups, on the other side, are significantly longer than the distances between the latter groups, which are hardly distinguished in the plot (Fig. 11). The severtzovi and outer groups being excluded from analysis, the distances between the other groups become visible (Fig. 12). The karelini and collium groups are significantly closer to each other than any other pair of groups, including the Mongolian populations. The nigrimontana and polii groups are at similar distances from the karelini and collium groups. Within the Kyrgyz-Kazakhstan type, the nigrimontana and polii groups are at the opposite poles, significantly distant from each other.

\section{Analysis of qualitative characters}

All qualitative characters noted in the list of cranial measurements (see Appendix 1) are very variable. The distinguished character variations were found in almost all groups with different frequencies, and no complete separation was achieved using qualitative characters.

The most efficient character for group separation is the inclination of the parietal part of the skull to the occipital plane. Skulls with almost coplanar parietal and occipital surfaces are typical for sheep from the Mongolian populations, and the angle-wise arrangement of these bones is more typical for sheep from the KyrgyzKazakhstan cranial type (Tab. 4).

By the location of palatine foramina, the Mongolian and Kyrgyz-Kazakhstan types differ less, but it is noteworthy that almost two thirds of Mongolian-type sheep have the palatine foramen in the maxillary bone and a few specimens have this foramen in the palatine bone. In the Kyrgyz-Kazakhstan type, the palatine foramen is 


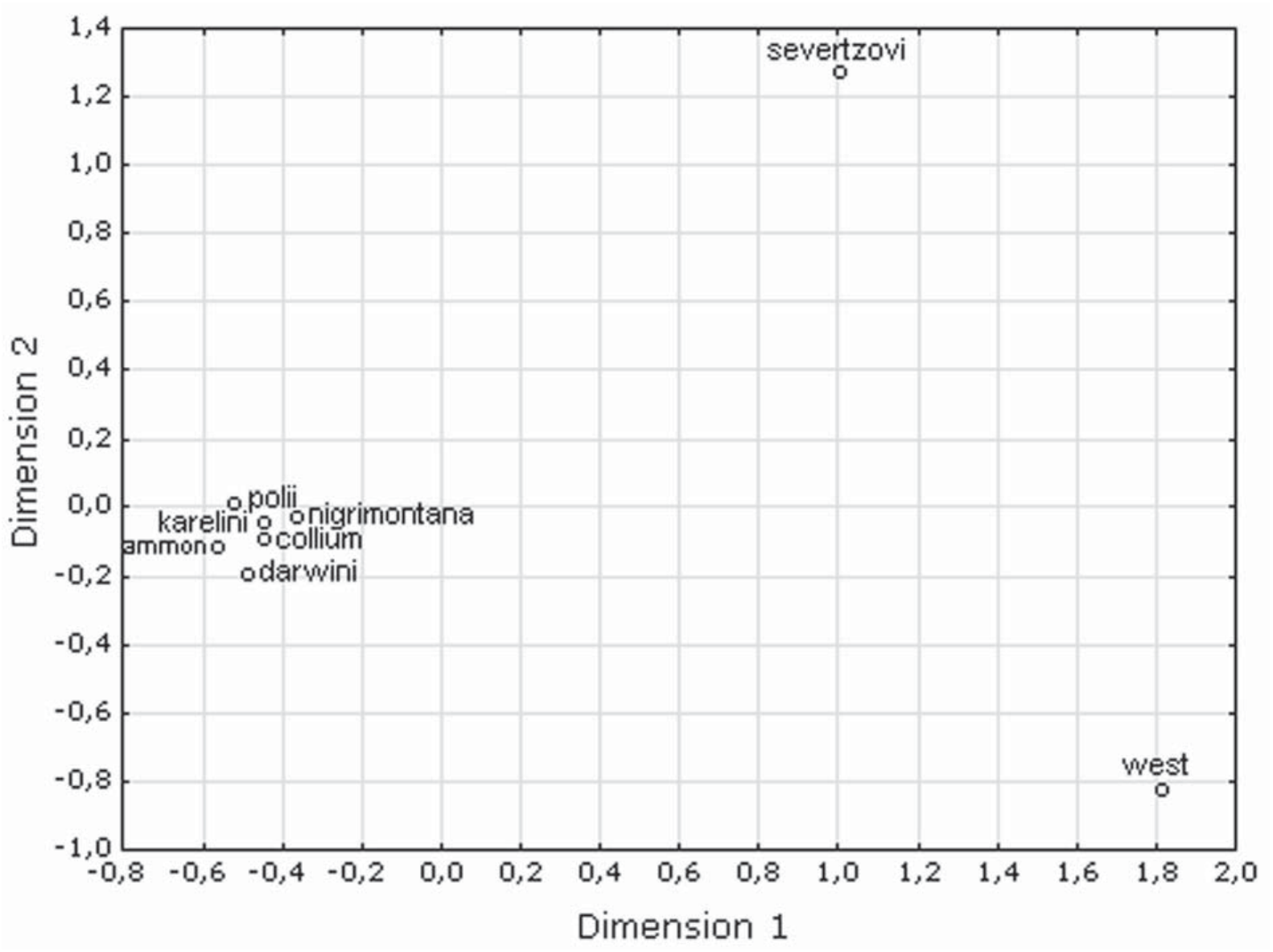

Figure 11. Plot of the final configuration of the studied Ovis groups in two-dimensional format from the multidimensional scaling analysis.

most frequently at the maxilla-palatine border, although there are skulls with the foramen in one of these bones (Tab. 4).

Different shapes of the suture between the frontal and nasal bones are observed with varying frequency; however, a semicircular suture is most frequent. A rectangular suture is observed in one third of collium specimens. A v-shaped suture was found only in a few darwini specimens (Tab. 4).

The darwini population is distinguished by the crosssection shape of horn base: almost half of animals have the tear-shaped cross-section of horns, because their frontal edges are strongly smoothed. In the other groups, the percentage of this shape is very low (Tab. 4).

\section{Discussion}

The analysis revealed three cranial types of argalis on the territory studied: Nuratau (Nuratau and Aktau ranges), Kyrgyz-Kazakhstan (Kazakhstan hillocky area, Tien Shan, Semirechensk region, Karatau Ranges, and the Pamirs), and Mongolian (Mongolian and Gobi Altai). These three types are distinguishable visually by the shape and structure of horns, cranial proportions, and absolute size. As for the latter two types, many authors already noted that they are well distinguishable from each other (Nasonov, 1923; Vinogradov et al., 1935; Heptner et al., 1961), and Nasonov (1923) rendered the status of species to these groups: $O$. polii and $O$. ammon, respectively. Severtzov's wild sheep, in the opinion of many authors, significantly differ from both argalis and sheep of the western range regions and occupy an intermediate position between them, as confirmed by our analysis of craniological characters.

The most indicative characters for the difference between cranial types are the ratio of the distance between parietal crests to the parietal bone length and the inclination of the parietal part the skull to the occipital plane. Gromova (1953) already used these characters for distinguishing genera Capra and Ovis. In Ovis ammon, these characters also effectively separate the cranial types. The most spaced parietal crests and almost coplanar parietal and occipital surfaces are typical for sheep of the Mongolian cranial type (Fig. 13D). Severtzov's wild sheep (Nuratau cranial type) have the closest parietal crests and their parietal and occipital surfaces meet at an angle significantly different from $180^{\circ}$ (Figs. 13A, 14A). These characters are shared for Severtzov wild sheep and moufflons and urials, as well as goats. The animals of the Kyrgyz-Kazakhstan type occupy an 


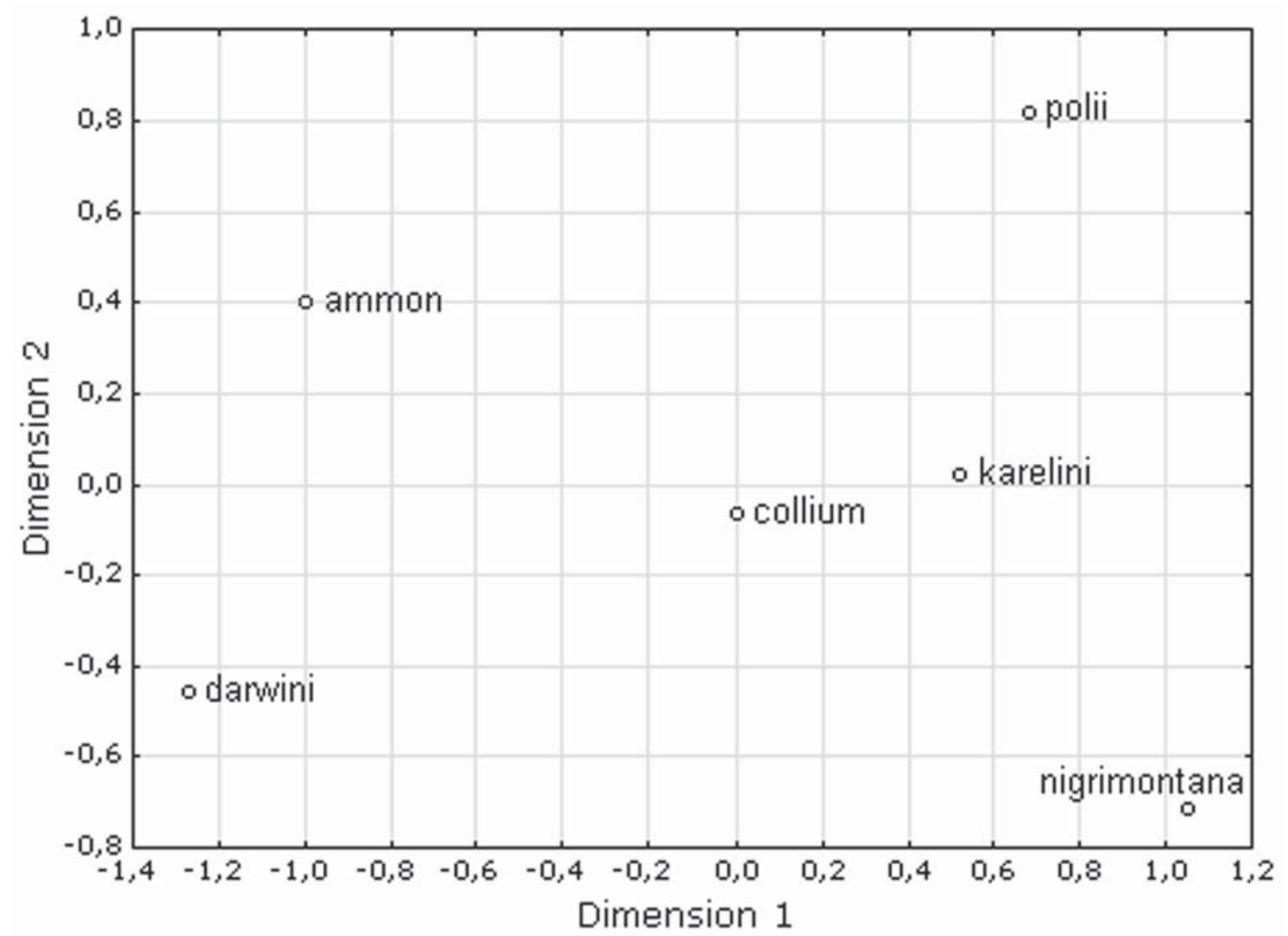

Figure 12. Plot of the final configuration of the studied Ovis groups in two-dimensional format from the multidimensional scaling analysis without considering the outer and $O$. a. severtzovi groups.

intermediate position between these extreme types (Figs. 13B, C, 14B, C).

Based on the hypothesis of Gromova (1953), who believed that wild sheep with craniological characters uniting them with goats should be considered as plesiomorphic, we may conclude that Severtzov wild sheep is the most plesiomorphic argali form. Mongolian sheep are most advanced evolutionally, and the Kyrgyz-Kazakhstan type is intermediate. Thus, on the species and subspecies levels, the decrease in the number of characters in common with Capra or close to them (we call it as 'caproid traits') is the main craniological evolutionary-morphological trend of the genus Ovis. Among argalis, these characters are the most pronounced in Severtzov's wild sheep and the least pronounced in Mongolian sheep.

The hypothesis of phylogenetic relations between the subspecies proposed on the basis of the revealed

Table 4. Occurrence frequency percentages of qualitative characters.

\begin{tabular}{|c|c|c|c|c|c|c|c|c|c|c|c|c|c|c|c|}
\hline & \multirow{2}{*}{$\mathrm{n}$} & \multicolumn{2}{|c|}{$\begin{array}{c}\text { Parietal-occipital } \\
\text { angle }\end{array}$} & \multirow{2}{*}{$\mathrm{n}$} & \multicolumn{3}{|c|}{$\begin{array}{l}\text { Palatine foramina } \\
\text { location }\end{array}$} & \multirow{2}{*}{$\mathrm{n}$} & \multicolumn{4}{|c|}{ Frontal-nasal suture shape } & \multirow{2}{*}{$\mathrm{n}$} & \multicolumn{2}{|c|}{$\begin{array}{c}\text { Cross-section shape } \\
\text { of horn bases }\end{array}$} \\
\hline & & $<180^{\circ}$ & $\sim 180^{\circ}$ & & $\begin{array}{l}\text { maxil- } \\
\text { lary }\end{array}$ & border & $\begin{array}{l}\text { palati- } \\
\text { ne }\end{array}$ & & $\begin{array}{l}\text { semicir- } \\
\text { cular }\end{array}$ & $\begin{array}{l}\text { rectangu- } \\
\quad \text { lar }\end{array}$ & $\begin{array}{l}\text { trian- } \\
\text { gular }\end{array}$ & v-shaped & & triangular & lens-like \\
\hline karelini & 13 & 100 & 0 & 13 & 38.5 & 46.2 & 15.4 & 13 & 84.6 & 15.4 & 0 & 0 & 12 & 100 & 0 \\
\hline collium & 47 & 70.2 & 29.8 & 45 & 15.5 & 66.7 & 17.8 & 42 & 57.1 & 33.3 & 9.6 & 0 & 36 & 94.4 & 5.6 \\
\hline polii & 32 & 96.9 & 3.1 & 20 & 30 & 50 & 20 & 20 & 75 & 5 & 20 & 0 & 33 & 93.9 & 6.1 \\
\hline $\begin{array}{l}\text { nigri- } \\
\text { montana }\end{array}$ & 14 & 85.7 & 14.3 & 14 & 42.9 & 35.7 & 21.4 & 13 & 76.9 & 15.4 & 7.7 & 0 & 11 & 90.9 & 9.1 \\
\hline ammon & 20 & 25 & 75 & 20 & 65 & 30 & 5 & 19 & 73.7 & 5.3 & 21.1 & 0 & 14 & 92.9 & 7.1 \\
\hline darwini & 27 & 33.3 & 66.7 & 27 & 63 & 33.3 & 3.7 & 25 & 68 & 8 & 4 & 20 & 22 & 54.5 & 45.5 \\
\hline
\end{tabular}




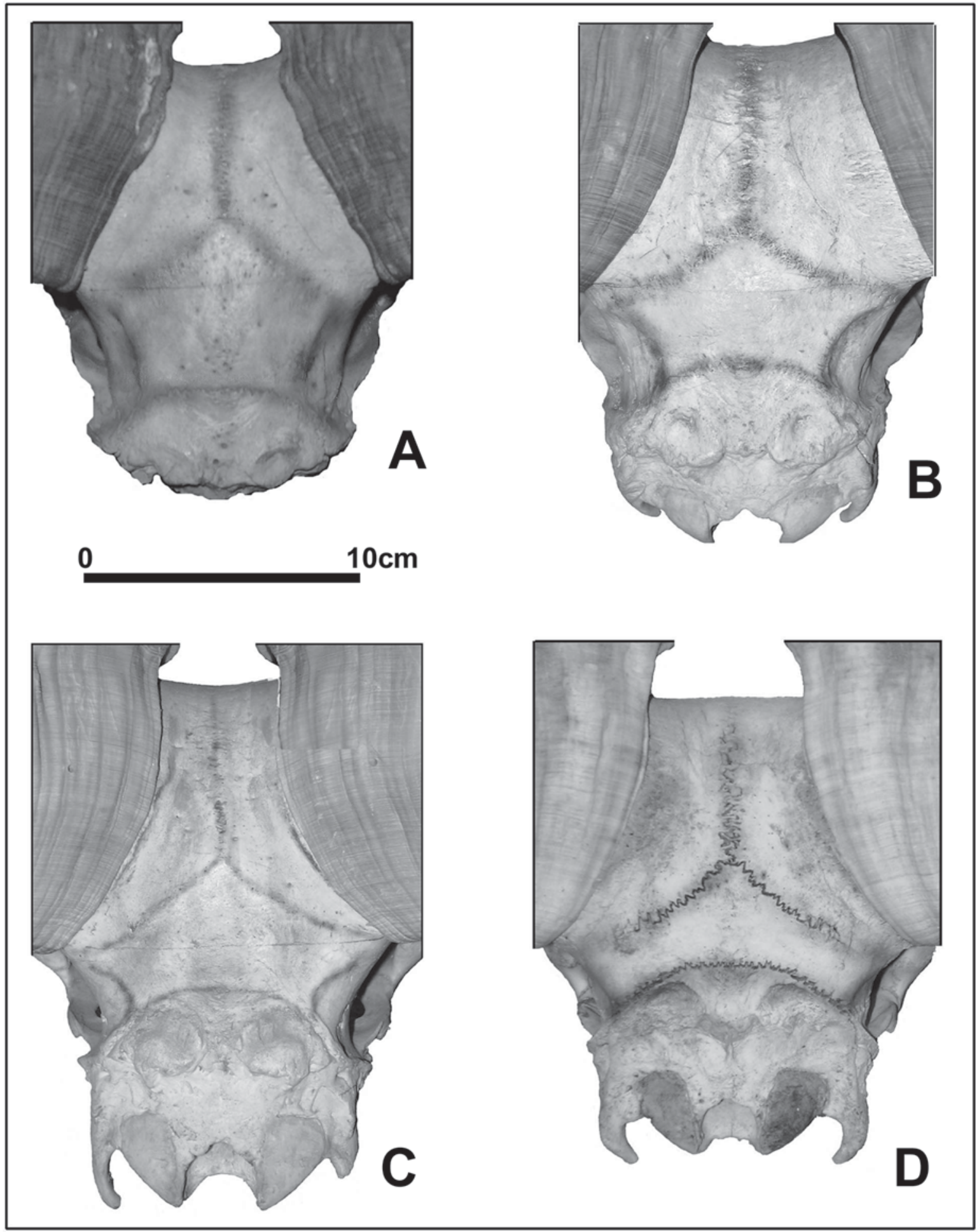

Figure 13. Cranial types of Ovis ammon, posterior view.

A - O. a. severtzovi (ZIN 12141, Uzbekistan, Nuratau Mountains), B - O. a. nigrimontana (ZIN 12084, Kazakhstan, Karatau Mountains), C - O. a. polii (ZIN 12094, Uzbekistan, Fergana, Alai Range), D - O. a. ammon (ZM MSU 132514, Mongolia, Borun Nurei Nuru Range). 


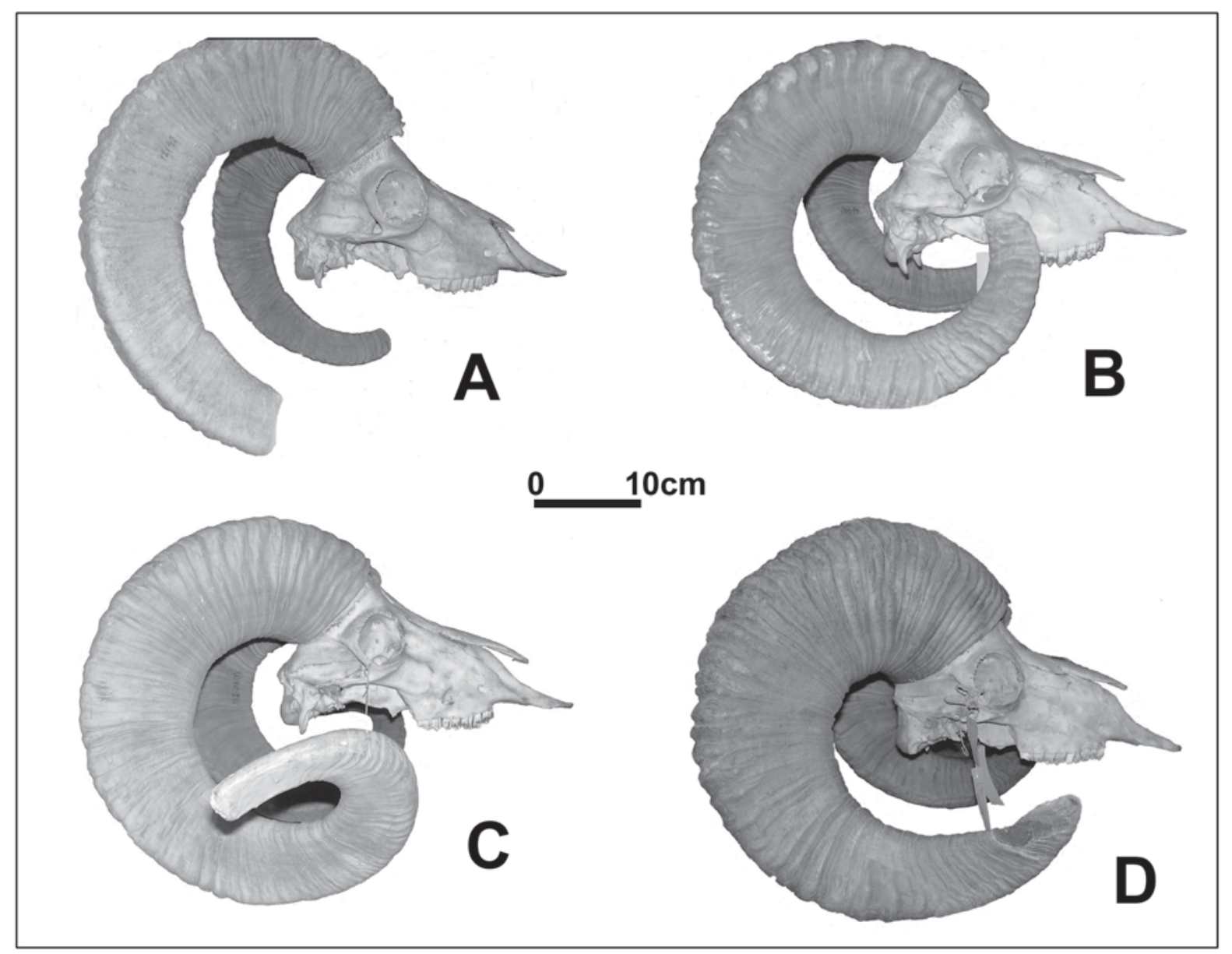

Figure 14. Cranial types of Ovis ammon, lateral view.

A - O. a. severtzovi (ZIN 12143, Uzbekistan), B - O. a. nigrimontana (ZIN 12084, Kazakhstan, Karatau Mountains), C - O. a. polii (ZIN 12094, Uzbekistan, Fergana, Alai Range), D - O. a. darwini (ZIN 23782, Mongolia, Central Gobi, Noin Bogdo).

craniological differences and evolutionary-morphological trend includes the following theses:

(1) O. a. nigrimontana, O. a. polii, O. a. karelini and O. a. collium are closer phylogenetically to one another than to the other subspecies;

(2) within this group, O. a. karelini and O. a. collium are closer phylogenetically to each other than to the other forms;

(3) O. a. ammon and O. a. darwini are closer phylogenetically to each other than to the other subspecies;

(4) $O$. a. severtzovi is a sister group with respect to all other argalis.

From the results of this study, it follows that Severtzov's wild sheep, which belongs to the Nuratau cranial type, is separate both from argalis and from moufflons and urials; it is difficult to classify among either of them from craniological data. In the space of multidimensional scaling axes (Fig. 11), it is located equally far from the argali group and the sheep of the western regions of the genus areal. Nevertheless, the cluster analysis combined the Severtzov's wild sheep with argalis into the same cluster (Fig. 10). In spite of the low number of Severtzov's sheep studied, the craniological data indicate that it is too isolated to be an Ovis ammon subspecies, as most contemporary authors believe (Lyapunova et al., 1997); it composes an independent group. Further integrated studies are necessary to establish the true taxonomic rank of Severtzov's wild sheep (argali subspecies or separate species).

The Kyrgyz-Kazakhstan cranial type includes the nigrimontana, karelini, collium and polii forms. Many authors (Nasonov, 1923; Heptner et al., 1961) noted the similarity of these forms, and Sopin (1982) even combined karelini, collium and polii into the same subspecies, because he found no significant differences among them in the standard craniological characters (skull length, skull breadth, snout length, lengths of the facial and cerebral parts of the skull). Our study showed that polii clearly differs from the other forms of this cranial type (Fig. 9). The polii group is characterizes by the larger span and length of horns compared to the other groups.

The nigrimontana form is also well distinguishable from the others by some characters. Relatively smoothed 
Table 5. The names of argali mostly used in the scientific and hunting references (trophy categories) as related to the cranial types substantiated in our work and corresponding to the taxonomic subdivisions of Ovis ammon.

\begin{tabular}{|c|c|c|c|}
\hline The most used subspecies names & Areal & Subspecies names from our study & Cranial type \\
\hline O. a. ammon & Mongolian Altai & \multirow{2}{*}{ O. a. ammon } & \multirow{3}{*}{ Mongolian } \\
\hline O. a. ssp. & Hangai & & \\
\hline O. a. darwini & Gobi Altai & O. a. darwini & \\
\hline O. a. polii & Pamirs & O. a. polii & \multirow{6}{*}{ Kyrgyz-Kazakhstan } \\
\hline O. a. karelini & Tien Shan & \multirow{4}{*}{ O. a. karelini } & \\
\hline O. a. littledalei & Junggar Alatau & & \\
\hline O. a. sairensis & Tarbagatai Range, Saur Range & & \\
\hline O. a. collium & Northeastern Kazakhstan & & \\
\hline O. a. nigrimontana & Karatau Range & O. a. nigrimontana & \\
\hline O. a. severtzovi & Nuratau Mountains & O. a. severtzovi & Nuratau \\
\hline
\end{tabular}

differences between nigrimontana and karelini may be attributed to the temporary overlapping of their areals in winter (Shaposhnikov, 1956); therefore, some individuals included in the nigrimontana group can be karelini. The nigrimontana sample is relatively small (16 animals), and this fact could strongly affect the results.

The subspecies rank of polii and nigrimontana goes unchallenged.

As for collium and karelini, animals of these groups are almost identical craniologically; our data did not confirm differences in the premaxillary length indicated by Tsalkin (1951). Hence, these two forms may be combined into a subspecies, O. a. karelini, as was done by Valdez (1982) and Geist (1991). Both names were established in the same work of Severtzov (1873); therefore, the subspecies retains the name of $O$. $a$. karelini, according to the First Reviser Principle (Valdez, 1982).

Cluster analysis, in contrast to discriminant analysis, revealed no significant differences between groups within the cluster of the Kyrgyz-Kazakhstan cranial type. This fact can be related to the fundamental differences in these methods, namely, to the inclusion of all characters (rather than only significant ones) into cluster analysis.

The Mongolian cranial type includes the ammon and darwini forms. These forms are very similar by the skull structure and differ only in size. Sopin \& Sukhbat (1983) proposed to render the rank of subspecies to these forms. The study of mtDNA of animals from different regions of Mongolia revealed a single subspecies (Tserenbataa et al., 2004). Our study showed that the populations of Mongolian and Gobi Altai are very similar, but well distinguishable by statistical methods. $O$. a. ammon and $O$. a. darwini constitute a group detached from other argalis and differentiated into two subspecies from the results of discriminant analysis (Tab. 3; Fig. 9). Cluster analysis showed that O. a. ammon and $O$. a. darwini are closer to each other compared to the members of other clusters, although insufficiently close to combine the Mongolian forms into a subspecies.
Thus, the argalis inhabiting the territory studied belong to six subspecies: $O$. a. severtzovi Nasonov, 1914, O. a. nigrimontana Severtzov, 1873, O. a. polii Blyth, 1941, O. a. karelini Severtzov, 1873 (=O. a. collium Severtzov, 1873), O. a. ammon (Linnaeus, 1758), and $O$. a. darwini Przewalski, 1883. The species also includes forms (one to four subspecies, from data of different authors) inhabiting China. The most used names of argalis of the territory studied as related to the cranial types substantiated in our work and corresponding to the taxonomic subdivisions of Ovis ammon are shown in Tab. 5 .

ACKNOWLEDGEMENTS. The authors sincerely acknowledge V.S. Lobachev, V.M. Malygin, S.V. Ogurtsov (Moscow State University), I.Ya. Pavlinov (MSU ZM), and A.O. Averianov (ZIN) for useful comments; T.M. Makhanova (Institute of Geology of Ore Deposits, Petrography, Mineralogy, and Geochemistry of the Russian Academy of Sciences) for significant technical assistance in the preparation of the paper; G.F. Baryshnikov, A.N. Tikhonov (ZIN), R.Zh. Baidavletov, and E. Ukrainskii (IZAG RK) for the presented opportunity to work with the osteological collections. The authors acknowledge with gratitude the Safari Club International Foundation for financial support of the work.

\section{References}

Fedosenko A.K. 2000. [Argali in Russia and Adjacent Countries (Population Status, Ecology, Behavior, Protection, and Economic Use)]. Moskva: GU Tsentrookhotkontrol'. 291 p. [in Russian].

Geist V. 1991. On the taxonomy of giant sheep (Ovis ammon Linnaeus, 1766) // Canadian Journal of Zoology. Vol.69. No.3. P.706-723.

Gromov I.M. \& Baranova G.I. (Eds.). 1981. [Catalogue of Mammals of the USSR. Pliocene-Present Days]. Leningrad: Nauka. 456 p. [in Russian].

Gromova V.I. 1953. [Osteological differences between genera Capra (goats) and Ovis (sheep): Guide for the determination of fossil remains] // Trudy Komissii po Izucheniyu Chetvertichnogo Perioda. T.10. No.1. P.1-122 [in Rus- 
sian].

Heptner V.G., Nasimovich A.A. \& Bannikov A.G. 1961. [Mammals of the Soviet Union. Vol.1. Perissodactyla and Artiodactyla]. Moskva: Vysshaya Shkola. 776 p. [in Russian].

Ishunin G.I. 1968. [New data on the taxonomy and morphology of Central Asiatic wild sheep] // Byulleten' Moskovskogo Obshchestva Ispytatelei Prirody, Otdel Biologicheskii. T.73. No.6. P.141-145 [in Russian].

Korobitsyna K.V., Nadler C.F., Vorontsov N.N. \& Hoffman R.S. 1974. Chromosomes of the Siberian snow sheep, Ovis nivicola, and implications concerning the origin of amphiberingian wild sheep (subgenus Pachyceros) // Quarternary Research. Vol.4. No.3. P.235-245.

Lyapunova E.A., Bunch T.D., Vorontsov N.N. \& Hoffman R.S. 1997. [Chromosome sets and taxonomic position of Severtzov argali (Ovis ammon severtzovi)] // Zoologicheskii Zhurnal. T.76. No.9. P.1083-1093 [in Russian].

Lydekker R. 1898. Wild Oxen, Sheep, and Goats of All Lands. London: Roland Ward. 239 p.

Mayr E. 1969. Principles of Systematic Zoology. New York: McGraw-Hill. 428 p.

Nasonov N.V. 1923. [Geographical Distribution of OldWorld Wild Sheep]. Petrograd. 255 p. [in Russian].

Orlov V.N. 1978. [Taxonomy of wild sheep and the origin of domestic sheep from caryological data] // Davletova L.V. (ed.). [Ecological-Morphological Features of Wild Relatives of Domestic Sheep]. Moskva: Nauka. P.5-46 [in Russian].

[Red Book of the Kazakh SSR: Rare and Threatened Species of Animals and Plants. Part 1. Vertebrates]. 1978. AlmaAta: Kainar. 208 p. [in Russian].

Rumyantsev B.F., Butarin N.S. \& Denisov V.F. 1935. [Hybridization of fat-tail sheep with Tien Shan wild sheep (Ovis polii karelini Sev.)] // Trudy Kirgizskoi Kompleksnoi Ekspeditsii 1933-1934. T.4. Vyp.3. P.15-58 [in Russian].

Severtzov N.A. 1873. [Arkhar (wild sheep)] // Priroda. T.1. P.144-245 [in Russian].

Shaposhnikov F.D. 1956. [Wild sheep of Western Tien Shan] // Priroda. No.1. P.109-110 [in Russian].

Sludskii A.A., Bekenov A.B., Zhevnerov V.V., Kapitonov V.I., Fadeev V.A. \& Fedosenko A.K. 1983. [Mammals of Kazakhstan. Vol.3. Part 3. Artiodactyla: Cavicornia].
Alma-Ata: Nauka. 245 p. [in Russian].

Sokolov I.I. 1959. [Fauna of the USSR. Mammals. Tome I. Vyp.3. Ungulates (orders Perissodactyla and Artiodactyla)]. Leningrad: Izdatel'stvo AN SSSR. 640 p. [in Russian].

Sopin L.V. 1982. [Interspecies structure of argali Ovis ammon (Artiodactyla, Bovidae)] // Zoologicheskii Zhurnal. T.61. No.12. P.1882-1892 [in Russian].

Sopin L.V. 1984. [Taxonomic position of Kyzyk-Kum sheep (Ovis ammon severtzovi)]//Zoologicheskii Zhurnal. T.63. No.5. P.189-192 [in Russian].

Sopin L.V. \& Sukhbat Kh. 1980. [Geographical variation of argali skull] // [Ungulates of the USSR (Ecology, Morphology, Use, and Protection): Abstracts]. Moskva: Nauka. P.374-375 [in Russian].

Sopin L.V. \& Sukhbat Kh. 1983. [Taxonomic rank of argali of Mongolian and Gobi Altai] // [Rare Mammal Species of the USSR and Their Protection: Proceedings of the Third All-Union Workshop]. Moskva: Nauka. P.213215 [in Russian].

Tsalkin V.I. 1951. [Wild Sheep of Europe and Asia]. Moskva: Moskovskoe Obschestvo Ispytatelei Prirody. 344 p. [in Russian].

Tserenbataa T., Ramey R.R., Ryder O.A., Quinn T.W. \& Reading R.P. 2004. A population genetic comparison of argali sheep (Ovis ammon) in Mongolia using the ND5 gene of mitochondrial DNA; implications for conservation // Molecular Ecology. Vol.13. No.5. P.1333-1339.

Valdez R. 1982. The Wild Sheep of the World. Mesilla, New Mexico: The Wild Goat and Sheep International. 186 p.

Vinogradov B.S., Pavlovskii E.N. \& Flerov K.K. 1935. [Animals of Tajikistan, their Life and Significance for Man]. Trydy Tadzhikskogo Tsentra. T.1. Zoologiya i Parazitologiya. Leningrad: Izdatel'stvo AN SSSR. 276 p. [in Russian].

Vorontsov N.N., Korobitsyna K.V., Nadler C.F., Hoffman R.S., Sapozhnikov G.V. \& Gorelov Yu.K. [Cytogenetic differentiation and species boundaries of true sheep (Ovis s. str.) of the Palearctic] // Zoologicheskii Zhurnal. T.51. No.8. P.1109-1122 [in Russian].

Wu C.H., Zhang Y.P., Bunch T.D., Wang S. \& Wang W. 2003. Mitochondrial control region sequence variation within the argali wild sheep (Ovis ammon): evolution and conservation relevance // Mammalia. T.67. No.1. P.109-118.

Appendix 1. The list of cranial measurements and qualitative characters of Ovis ammon used in the work; qualitative characters are denoted by asterisk (*):

1. Total breadth - in the broadest portion (posterior orbit margins) (Fig. 1).

2. Interorbital breadth - in the narrowest portion between orbits (Fig. 1).

3. Postorbital breadth - in the narrowest portion between the posterior orbit edge and the horn base (Fig. 1).

4. Nasal length (Fig. 1).

5. Nasal breadth - in the broadest portion (Fig. 1).

6. Distance from the forehead crest to the frontal process margin (Fig. 1).

7. Distance from the forehead crest to the middle of the frontal-nasal suture (Fig. 1).

8. *Frontal foramen shape (round/oval/elongate).

9. Distance from the forehead crest to the middle of the line joining the prosthions (Fig. 1).

10. * Shape of the frontal-nasal suture (semicircular/rectangular/triangular/v-shaped).

11. Straight frontal length - from the middle of the frontal-parietal suture to the middle of the frontal-nasal suture (Fig. 2).

12. Curved frontal length (Fig. 2).

13. Distance from the forehead crest to the anterior nasal edge (Fig. 1). 
14. Length of the braincase — from the posterior orbit edge to the middle of the line joining the most posteriorly projected points of the skull (Fig. 2).

15. Length of the facial part of skull - from the posterior orbit edge to the prosthion (Fig. 2).

16. *Joining of premaxillary and nasal bones (yes/no).

17. * Location of the anterior orbit edge with respect to the last molar (behind M3 / at the M3 level / at the M2 level).

18. *Joining of the orbital process of basisphenoid with the parietal bone (yes/no).

19. * The angle between parietal and occipital bone surfaces $\left(<180^{\circ} / 180^{\circ}\right)$ (Fig. 2).

20. * Location of the front of horn base with respect to the posterior orbit edge (behind orbit / at the level of back orbit half / at the level of front orbit half).

21. Orbital diameters: (a) maximum and (b) minimum values (Fig. 2).

22. *Level of the anterior jugal edge (lower prominence) with respect to teeth (behind M3 / at the M3 level / at the M2 level).

23. Jugal length - from the branching point to the most anterior point of the bone at the branching level (Fig. 2).

24. Snout length - from the anterior orbit edge to the prosthion (Fig. 2).

25. Snout height - from the level of the frontal-nasal suture to the anterior edge of the pterygoid process (Fig. 2).

26. Premaxillary length (Fig. 2).

27. Lacrimal length (Fig. 1).

28. Lacrimal breadth - at the anterior orbit edge (Fig. 1).

29. Orbitosphenoid length.

30. Distance from the dorsal orbitosphenoid point to the ventral point of the basisphenoid-palatine suture.

31. *Parietal profile (flat/convex/concave).

32. *Mastoid-parietal joint (yes/no).

33. Minimum distance between parietal crests (Fig. 3).

34. Parietal length in the midline (Fig. 3).

35. Skull height - from the forehead crest to the middle of the line joining the ventral points of occipital condyles (Fig. 3).

36. Distance from the middle of the frontal-parietal suture to the upper edge of foramen magnum (Fig. 3).

37. Minimum breadth of the cranial part of skull — at the level of parietal-squamosal suture (Fig. 3).

38. Distance from the forehead crest to the upper edge of foramen magnum (Fig. 3).

39. Foramen magnum diameters: (a) perpendicularly and (b) along the skull axis (Fig. 4).

40. Occipital breadth - between the lateral edges of mamillary processes (Fig. 3).

41. *Location of palatal incisure with respect to the last molar (behind M3 / at the M3 level / at the M3-M2 border level / at the M2 level).

42. Jugal breadth in the narrowest portion before the branching point (Fig. 4).

43. Ventral premaxillary length - from the anterior end to the point of the bend of the lateral portion (Fig. 4).

44. Incisive foramen length (Fig. 4).

45. Total tympanic bulla breadth (Fig. 4).

46. Tympanic bulla length (Fig. 2).

47. *Location of palatine foramina (on maxillary / on palatine / on maxillary-palatine border).

48. Prealveolar distance - from the anterior edge of the first premolar to the prosthion (Fig. 4).

49. Skull breadth at the level of facial tubercles (Fig. 1).

50. Skull breadth at the level of the anterior edge of the first premolar (Fig. 1).

51. Ventral maxillary length - in the midline from the maxillary-palatine suture to the point of bone branching at the level of the posterior edge of incisive foramina (Fig. 4).

52. *Palatal incisure shape (semicircular/triangular/v-shaped).

53. Basal skull length - from the ventral edge of foramen magnum to the prosthion (Fig. 4)

54. Total length - from the middle of the line joining the most posteriorly projected points of the skull (without horns) to the prosthion (Fig. 4).

55. *Basioccipital process at the level of external acustic meatus (yes/no/broad).

56. Condylobasal length - from the line of the posterior edge of the occipital condyles to the prosthion (Fig. 4).

57. Palatine bone length — distance from the palatal incisure to the anterior palatine edge along the midline (Fig. 4).

58. Total distance between upper cheek tooth rows at the M3 level (Fig. 4).

59. Upper cheek tooth row length — from the anterior edge of the first premolar to the posterior edge of the last molar, M3

(Fig. 4).

60. Upper premolar row length (Fig. 4).

61. Upper molar row length (Fig. 4).

62. Length of the M3 (Fig. 4).

63. *Premolar P2 (yes/no).

64. *Cross-section shape of horn bases (lens-like/triangular).

65. *Horn type (homonymous/heteronymous/perverted).

66. Distance between horn tips.

67. Total horn span.

68. Horn length along the frontal side.

69. Basal horn circumference (Fig. 5).

70. Horn circumference at the first quarter (Fig. 5).

71. Horn circumference at the second quarter (Fig. 5).

72. Horn circumference at the third quarter (Fig.5). 
73. Maximum horn diameter.

74. Mandible depth - from the coronoid process crest down to the level of the ventral edge of horizontal ramus (Fig. 6).

75. Mandible length - from the posterior surface of articular condyle to the most anterior point of mandible (incisors) (Fig. 6).

76. Lower cheek tooth row length (Fig. 6).

77. Mandibular diastem length (Fig. 6).

78. Lower premolar row length (Fig. 6).

79. Lower molar row length (Fig. 6)

80. Mandible depth at the level of the last lower molar, m3 (Fig.6).

81. Length of the m3 (Fig. 6).

82. Length of the lower incisors, $\mathrm{i} 1-\mathrm{i} 3$.

Appendix 2. Ratios of Ovis ammon cranial characters included into statistical analysis (the numbers of characters according to Appendix 1 are given in column 3).

\begin{tabular}{|c|c|c|}
\hline \multicolumn{3}{|c|}{ Skull } \\
\hline total breadth & & 1 \\
\hline total breadth & interorbital breadth & $1 / 2$ \\
\hline total breadth & postorbital breadth & $1 / 3$ \\
\hline total breadth & $\begin{array}{l}\text { forehead crest - nasal- } \\
\text { frontal suture }\end{array}$ & $1 / 7$ \\
\hline total breadth & occipital breadth & $1 / 40$ \\
\hline total breadth & $\begin{array}{l}\text { breadth at the level of facial } \\
\text { tubercles }\end{array}$ & $1 / 49$ \\
\hline nasal length & nasal breadth & $4 / 5$ \\
\hline nasal length & $\begin{array}{l}\text { forehead crest - nasal- } \\
\text { frontal suture }\end{array}$ & $4 / 7$ \\
\hline $\begin{array}{l}\text { forehead crest - anterior } \\
\text { nasal edge }\end{array}$ & nasal length & $13 / 4$ \\
\hline $\begin{array}{l}\text { forehead crest - frontal } \\
\text { process end }\end{array}$ & $\begin{array}{l}\text { forehead crest - nasal- } \\
\text { frontal suture }\end{array}$ & $6 / 7$ \\
\hline forehead crest - prosthion & & 9 \\
\hline forehead crest - prosthion & total breadth & $9 / 1$ \\
\hline forehead crest - prosthion & nasal length & $9 / 4$ \\
\hline $\begin{array}{l}\text { forehead crest - } \\
\text { prosthion }\end{array}$ & $\begin{array}{l}\text { forehead crest - nasal- } \\
\text { frontal suture }\end{array}$ & $9 / 7$ \\
\hline $\begin{array}{l}\text { forehead crest - } \\
\text { prosthion }\end{array}$ & $\begin{array}{l}\text { forehead crest - anterior } \\
\text { nasal edge }\end{array}$ & $9 / 13$ \\
\hline forehead crest - prosthion & facial length & $9 / 15$ \\
\hline forehead crest - prosthion & skull height & $9 / 35$ \\
\hline forehead crest - prosthion & occipital breadth & $9 / 40$ \\
\hline $\begin{array}{l}\text { forehead crest - } \\
\text { prosthion }\end{array}$ & $\begin{array}{l}\text { breadth at the level of facial } \\
\text { tubercles }\end{array}$ & $9 / 49$ \\
\hline forehead crest - prosthion & condylobasal length & $9 / 56$ \\
\hline curved frontal length & straight frontal length & $12 / 11$ \\
\hline facial length & cranial length & $15 / 14$ \\
\hline facial length & snout length & $15 / 24$ \\
\hline $\begin{array}{l}\text { orbital diameter along } \\
\text { the axis }\end{array}$ & $\begin{array}{l}\text { orbital diameter across the } \\
\text { axis }\end{array}$ & $21 \mathrm{a} / 21 \mathrm{~b}$ \\
\hline jugal length & jugal breadth & $23 / 42$ \\
\hline premaxillary length & ventral premaxillary length & $26 / 43$ \\
\hline premaxillary length & prealveolar distance & $26 / 48$ \\
\hline
\end{tabular}

\begin{tabular}{|c|c|c|}
\hline \multicolumn{3}{|c|}{ Skull } \\
\hline lacrimal length & lacrimal breadth & $27 / 28$ \\
\hline $\begin{array}{l}\text { Orbitosphenoid - } \\
\text { ventral suture edge }\end{array}$ & orbitosphenoid length & $30 / 29$ \\
\hline $\begin{array}{l}\text { distance between } \\
\text { parietal crests }\end{array}$ & parietal length & $33 / 34$ \\
\hline skull height & & 35 \\
\hline skull height & total breadth & $35 / 1$ \\
\hline skull height & $\begin{array}{l}\text { height: nasal — pterygoid } \\
\text { process }\end{array}$ & $35 / 25$ \\
\hline skull height & minimum cranial breadth & $35 / 37$ \\
\hline $\begin{array}{l}\text { forehead crest - } \\
\text { foramen magnum }\end{array}$ & $\begin{array}{l}\text { frontal-parietal suture - } \\
\text { foramen magnum }\end{array}$ & $38 / 36$ \\
\hline $\begin{array}{l}\text { frontal-parietal suture - } \\
\text { foramen magnum }\end{array}$ & minimum cranial breadth & $36 / 37$ \\
\hline occipital breadth & minimum cranial breadth & $40 / 37$ \\
\hline occipital breadth & $\begin{array}{l}\text { foramen magnum diameter } \\
\text { perpendicular to the axis }\end{array}$ & $40 / 39 a$ \\
\hline $\begin{array}{l}\text { foramen magnum } \\
\text { diameter perpendicular } \\
\text { to the axis }\end{array}$ & $\begin{array}{l}\text { foramen magnum diameter } \\
\text { along to the axis }\end{array}$ & $39 a / 39 b$ \\
\hline $\begin{array}{l}\text { ventral premaxillary } \\
\text { length }\end{array}$ & incisive foramen length & $43 / 44$ \\
\hline tympanic bulla length & tympanic bulla breadth & $46 / 45$ \\
\hline prealveolar distance & ventral premaxillary length & $48 / 43$ \\
\hline prealveolar distance & $\begin{array}{l}\text { upper cheek tooth row } \\
\text { length }\end{array}$ & $48 / 59$ \\
\hline snout length & prealveolar distance & $24 / 48$ \\
\hline $\begin{array}{l}\text { breadth at the level of } \\
\text { facial tubercles }\end{array}$ & breadth just before P2 & $49 / 50$ \\
\hline ventral maxillary length & palatine length & $51 / 57$ \\
\hline $\begin{array}{l}\text { palate length (maxillary } \\
+ \text { palatine) }\end{array}$ & $\begin{array}{l}\text { breadth between tooth rows } \\
\text { at the M3 level }\end{array}$ & $\begin{array}{c}(51+57) \\
158\end{array}$ \\
\hline total skull length & & 54 \\
\hline total skull length & total breadth & $54 / 1$ \\
\hline total skull length & basal skull length & $54 / 53$ \\
\hline $\begin{array}{l}\text { condylobasal skull } \\
\text { length }\end{array}$ & skull height & $56 / 35$ \\
\hline
\end{tabular}




\section{Appendix 2.}

\begin{tabular}{|l|l|c|}
\hline \multicolumn{3}{|c|}{ Skull } \\
\hline $\begin{array}{l}\text { upper cheek tooth row } \\
\text { length }\end{array}$ & $\begin{array}{l}\text { breadth between tooth rows } \\
\text { at the M3 level }\end{array}$ & $59 / 58$ \\
\hline $\begin{array}{l}\text { upper cheek tooth row } \\
\text { length }\end{array}$ & upper premolar row length & $59 / 60$ \\
\hline $\begin{array}{l}\text { upper cheek tooth row } \\
\text { length }\end{array}$ & upper molar row length & $59 / 61$ \\
\hline $\begin{array}{l}\text { upper cheek tooth row } \\
\text { length }\end{array}$ & M3 length & $59 / 62$ \\
\hline $\begin{array}{l}\text { upper premolar row } \\
\text { length }\end{array}$ & upper molar row length & $60 / 61$ \\
\hline $\begin{array}{l}\text { upper premolar row } \\
\text { length }\end{array}$ & M3 length & $60 / 62$ \\
\hline upper molar row length & M3 length & $61 / 62$ \\
\hline \multicolumn{2}{|c|}{ Horns } & $69 / 70$ \\
\hline postorbital breadth & total horn span \\
\hline total horn span & distance between horn tips & $67 / 66$ \\
\hline horn length & total horn span & 68 \\
\hline horn length & basal circumference & $68 / 69$ \\
\hline horn length & maximum diameter \\
\hline basal circumference & quarcumference at the first & $69 / 73$ \\
\hline basal circumference & 687 \\
\hline
\end{tabular}

\begin{tabular}{|l|l|c|}
\hline \multicolumn{3}{|c|}{ Horns } \\
\hline basal circumference & $\begin{array}{l}\text { circumference at the } \\
\text { second quarter }\end{array}$ & $69 / 71$ \\
\hline basal circumference & $\begin{array}{l}\text { circumference at the third } \\
\text { quarter }\end{array}$ & $69 / 72$ \\
\hline \multicolumn{3}{|l|}{ Mandible } \\
\hline length & total depth & $75 / 74$ \\
\hline length & diastem length & $75 / 77$ \\
\hline total height & depth at the m3 level & $74 / 80$ \\
\hline $\begin{array}{l}\text { lower cheek tooth row } \\
\text { length }\end{array}$ & diastem length & $76 / 77$ \\
\hline $\begin{array}{l}\text { lower cheek tooth row } \\
\text { length }\end{array}$ & lower premolar row length & $76 / 78$ \\
\hline $\begin{array}{l}\text { lower cheek tooth row } \\
\text { length }\end{array}$ & lower molar row length & $76 / 79$ \\
\hline $\begin{array}{l}\text { lower cheek tooth row } \\
\text { length }\end{array}$ & m3 length & $76 / 81$ \\
\hline $\begin{array}{l}\text { lower cheek tooth row } \\
\text { length }\end{array}$ & lower incisor row length & $76 / 82$ \\
\hline lower premolar row length & lower molar row length & $78 / 79$ \\
\hline lower premolar row length & m3 length & $78 / 81$ \\
\hline lower molar row length & m3 length & $79 / 81$ \\
\hline incisor row length & lower incisor row length & $77 / 82$ \\
\hline diastem length & & 82 \\
\hline
\end{tabular}

